\title{
Angioedema Due to the Combination Everolimus- Ace Inhibitor in Renal Cell Cancer
}

\author{
Patricia Ibeas-Millán*, Gema Pulido-Cortijo, Raquel Cervera-Calero and Carmen Perezagua Marín \\ Medical Oncology Departments, Hospital Universitario Del Henares, Spain
}

Submission: April 06, 2017; Published: April 11, 2017

"Correspondence Address: Patricia Ibeas-Millán, Department of Medical Oncology. Hospital del Henares, Avda Marie Curie, S/N, 28822

Coslada, Madrid, Spain, Tel: +34911912495; Fax:+34911912284; Email: patoibeas@hotmail.com

Abstract

We present the case of a 62 -year-old male patient with renal cell cancer, with a long history of hypertension under treatment with enalapril $10 \mathrm{mg}$. At the beginning of everolimus, as second line treatment, he was admitted in emergency room diagnosed of lingual angioedema that required ICU admission and a tracheostomy.

Keywords: Angioedema; Angiotensin Convertin Enzime (ACE); Everolimus; Renal cell cancer

\section{Introduction}

The standard treatment for advanced renal carcinoma is based upon targeted therapies that include tyrosine kinase inhibitors and mTOR pathway inhibitors. The PI3K-Akt-mTOR pathway is a cornerstone for certain cellular functions such as protein synthesis, glucose metabolism, cell migration and cell survival. Temsirolimus and everolimus, whose antitumoral effect is a consequence of its inhibition of the mTOR pathway, have been tested in phase III trials and approved for the treatment of advanced renal carcinoma. The most common side effects associated with mTOR inhibitors are well known: pneumonitis, asthenia, rash, anaemia... However, there are little data published on angioedema linked to the use of Angiotensin Convertin Enzyme (ACE) inhibitors in combination with everolimus in Oncology.

\section{Case Report}

We report the case of a 62 years old male patient with no known allergies and a long history of hypertension under treatment with enalapril $10 \mathrm{mg}$, diabetes mellitus type II managed with insulin therapy and metformin/vildagliptin and dyslipidemia treated with atorvastatine. He was diagnosed in April 2011 of a stage IV clear cell renal carcinoma (two lung lesions, one located in the upper left lobe and the other one in the lower right lobe).

He began a $50 \mathrm{mg}$ per day 4 weeks on/2 weeks off scheme as first line treatment with sunitinib in May 2011 that had to be reduced to $37.5 \mathrm{mg}$ per day due to a grade II asthenia. After an initial response to sunitinib, the patient was referred to Thoracic
Surgery for lung lesions resection. Both nodes were removed in october 2011, with anatomopathological report of clear cell carcinoma metastases.

In January 2012 treatment with sunitinib was resumed at $37,5 \mathrm{mg}$, and was discontinued in December 2012 after completing one year of complementary treatment without evidence of disease in imaging test. In November 2013, CT scan showed mediastinal lymph node progression and treatment with sunitinib at $37,5 \mathrm{mg}$ was resumed once again. The disease was stabilized up until July 2014, when lymphatic progression occurred. Treatment was switched to everolimus $10 \mathrm{mg}$ (mTOR inhibitor) per day.

10 days after treatment began the patient was admitted in the emergency rescue of our institution referring tongue swelling, difficulty swallowing and hoarse voice. The patient rapidly developed cervical swelling, disphagia with sialorrea and dysphonia worsened. An angioedema was diagnosed and a $160 \mathrm{mg}$ methylprednisolone iv, $200 \mathrm{mg}$ hydrocortisone, polaramine iv, omeprazole $40 \mathrm{mg}$, $1 \mathrm{mg}$ adrenalin sc, $600 \mathrm{mg}$ $\mathrm{N}$-acetylcysteine and 2 gr Amoxicillin-clavulanic treatment was administered. In absence of clinical improvement and in view of upper airways obstruction, the patient required ICU admission and a tracheostomy.

Neck CT scan showed generalized edema and effacement of the main surrounding fat planes that extended up to the base of tongue (Figures 1\&2). After a month long hospitalisation and recovery, the patient was reassessed. Given the toxicity of the 


\section{Cancer Therapy \& Oncology International Journal}

previous treatment, we decided to switch to axitinib $5 \mathrm{mg}$ bid Up until now, the patient is under this treatment and the disease is stabilized.
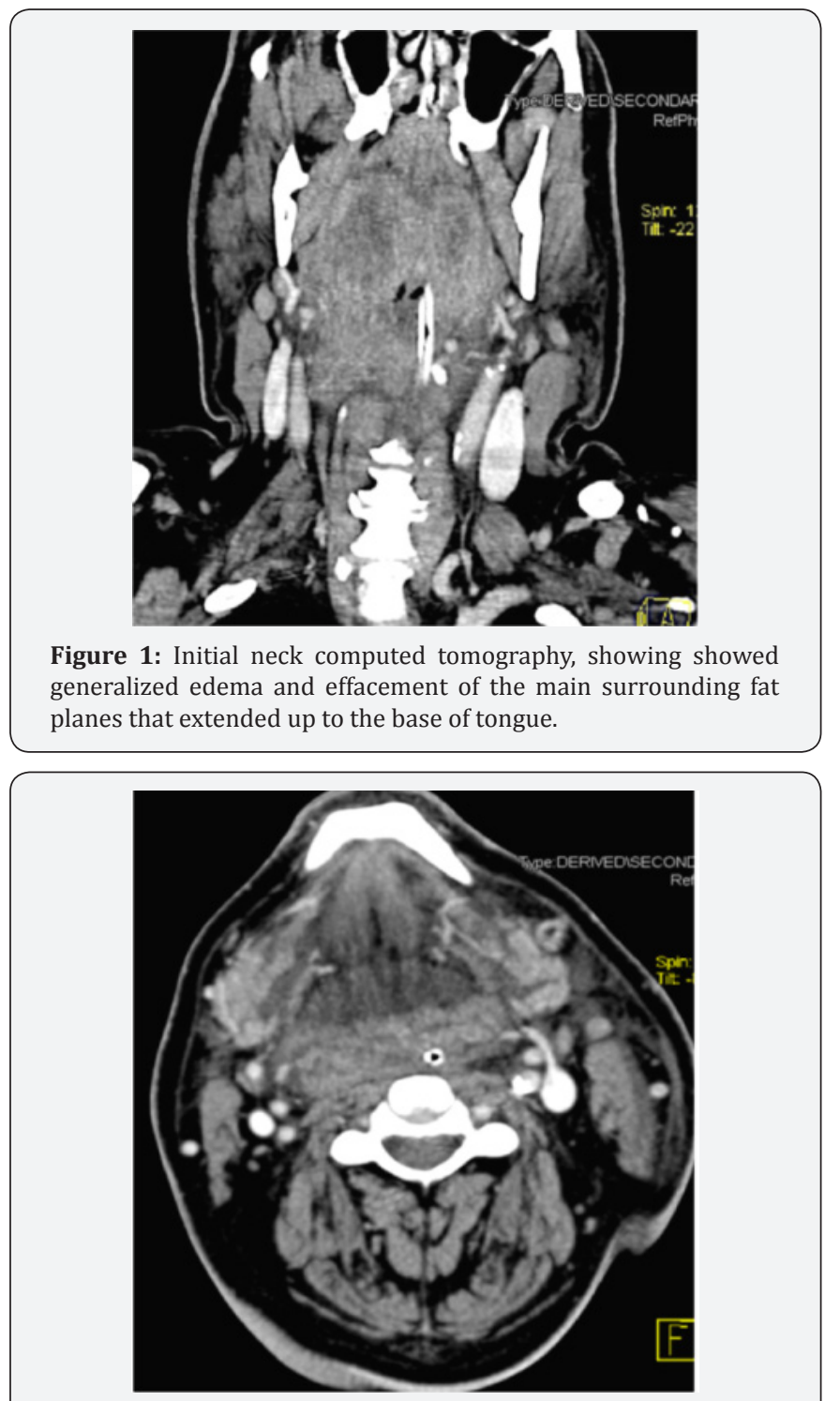

Figure 2: Initial neck computed tomography, showing showed generalized edema and effacement of the main surrounding fat planes that extended up to the base of tongue.

\section{Discussion}

Lingual angioedema as a side effect of a combination of everolimus and a angiotensin convertin Enzyme (ACE) inhibitor has been widely published in transplants $[1,2]$. This is so, that its combined use is discouraged. However, if we perform a search in "pubmed" using the words "everolimus" and "angioedema" and "renal carcinoma" only two cases have been published and both were treated with lisinopril [3,4]. Our patient was under treatment with enalapril for many years. The mechanism of action proposed is a reduction of degradation of bradykinin by ACE inhibitors, causing an increase of bradykinin and, as a consequence, a higher vasodilation and an increase of permeability of blood vessels [5]. Nonetheless, it is still unclear why it appears when using ACE. The precise incidence of lingual angioedema among metastatic renal carcinoma patients is unknown. If the incidence is as high as the one reported for transplant patients, we believe the oncology community should be aware of it, mainly because of:

I. There is an increase in the use of everolimus in oncology, such as in breast cancer for example.

II. Everolimus is a second line treatment for renal cancer, and many patients are under full-dose treatment with ACE inhibitors due to the hypertension caused by first line treatments as sunitinib.

\section{Conclusion}

As a conclusion, and until more information is available, interruption of ACE inhibitors or the use of other antihypertensive treatments, previous to the use of mTOR inhibitors, should be highly considered.

\section{Conflict of Interest}

The authors have no actual, potential, real or apparent interest to declare and have no involvement that might raise the question of bias in the work report

\section{Reference}

1. Fuchs U, Zittermann A, Berthold HK, Tenderich G, Deyerling KW, et al. (2005) Immunosup- pressive therapy with everolimus can be associated with potentially life-threatening lingual angioedema. Transplanta tion 79(8): 981-983.

2. Rothenburger M, Zuckermann A, Bara C, Hummel M, Struber M, et al (2007) Recommendations for the use of everolimus (certican) in heart transplantation: Results from the Second German-Austrian Certican Consensus Conference. J Heart Lung Transplant 26(4): 305-311.

3. Mackenzie M, Wood LA (2010) Lingual angioedema associated with everolimus. Acta Oncologica 49(1): 107-109.

4. Rothermundt C, Gillessen S (2013) Angioedema in a Patient With Renal Cell Cancer Treated With Everolimus in Combination With an Angiotensin-Converting Enzyme Inhibitor. J Clin Oncol 31(5): e57-e58.

5. Nussberger J, Cugno M, Amstutx C, Cicardi M, Pellacani A, et al. (1998) Plasma Bradykinin in angio-oedema. Lancet 351(9117):1693-1697. 


\section{Your next submission with Juniper Publishers} will reach you the below assets

- Quality Editorial service

- Swift Peer Review

- Reprints availability

- E-prints Service

- Manuscript Podcast for convenient understanding

- Global attainment for your research

- Manuscript accessibility in different formats

( Pdf, E-pub, Full Text, Audio)

- Unceasing customer service

Track the below URL for one-step submission https://juniperpublishers.com/online-submission.php 